\title{
Corporate Governance and Credibility Gap: Empirical Evidence from Jordan
}

\author{
Madher Ebrahim Hamdallah \\ Correspondence: Madher Ebrahim Hamdallah, Faculty of Economics and Administrative science, Department of \\ Accounting, Al-zaytoonah University, Amman, Jordan. E-mail: M.Hamdella@zuj.edu.jo
}

Received: August 26, 2012

Accepted: September 13, 2012

Online Published: October 19, 2012

doi:10.5539/ibr.v5n11p178

URL: http://dx.doi.org/10.5539/ibr.v5n11p178

\begin{abstract}
This study aimed to examine what shareholders think about auditors in relation with corporate governance by using an inferential descriptive statistical analysis. Corporate governance has shown flaws; where part of it was done to the weakness of shareholders activism, and because auditing is a very important avenue of faithful representation (credibility gap) of financial statements, and shareholders depend on auditors' reports, this article utilized primary data by distributing a questionnaire to the shareholders representatives in Amman Stock Exchange that focused on the affect of the auditors' independency and code of ethics on the credibility gap, including demographic factors. Results showed a positive relationship between the auditors' independency and there implementation of the code of ethics on the credibility gap, and results also showed that females were more realizable of the credibility gap than males.
\end{abstract}

Keywords: corporate governance, independency of the auditor, code of ethics, credibility gap

\section{Introduction}

Lots think that the financial crisis of 2008 was doing to the weak mechanisms of corporate governance, for that callings rose to increase disclosure, greater independence of board members, and proxy access for shareholders (Rodrigues, 2011). Corporate governance is built on many factors such as audit and compliance, corporate governance policies and corporate governance practices.

Berenbeim (2012) argued that in order to be successful there should be a balance between the two potential competing performers. First, the directors. Second, who watch those directors, such as legal and regulatory authorities, auditors, shareholders, or the stake supervisory authorities? All stakeholders have faith in the ability of code of ethics, which if practiced in letter and spirit shall prevent corporate mishaps (Gopinath, 2010). Kangarluie and Bayazidi (2011) said that corporate governance variables include percent of independent outside directors on the board, ownership structure and audit type.

Shareholders decisions are built after taking into consideration reports confirmed by the auditors. So auditors have a great responsibility; for their liability is not only towards the corporation, but also towards the investors in that corporation presented by the shareholders. For that the main objective of this study is to find auditors' independency and code of ethics in relation with credibility gap.

\subsection{Corporate Governance Definition}

There is no precise definition of corporate governance; for Scheifer and Vishny (1997) defined it as a method by which firm suppliers can make sure that their investment in a firm will be returned. While John and Senbet (1998) said that it is a competitive mechanism by which shareholders control the actions of managers and decision makers inside a firm. Ulaș and Alakavuklar (2011) argued that corporate governance aims to prevent management failure and managerial bad intention, and try to cover the issues that were not covered by existing laws. Cadbury (2000) added that it is a mechanism through which an organization is directed and controlled. Aguilera and Jackson (2003) stated that corporate governance is referred to the distribution of privileges and accountabilities amongst numerous performers who are involved in the corporate organization. Picou and Rubach (2006) defined it as a set of rules, deeds, and motives used for equalizing the benefits of managers and shareholders.

Ma'atoofi and Ahmadian (2011) said it is a mechanism specifying how supreme decision makers of organization shareholders are to supervise and direct the contractual relations of managers. Kangarluie and Bayazidi (2011) 
added to the above that it is a corporate control by intermediaries, and that auditors are responsible for controlling and certifying the annual balance sheets and reports of the corporation. Bandyopadhayay (2011) defined corporate governance as a system of making management accountable towards the stakeholders, and that a good corporate governance is concerned with the morals, ethics, values, parameters, conduct behavior of the company and its management, and added that the basic segment underlying principles of corporate governance is integrity and fairness.

\subsection{Independence of the Auditor}

Being an external auditor is not an easy profession, for there are lots of responsibilities awaiting them, and auditors should have certain factors and characteristics. The external audit factors include both auditors' independence and audit quality (Habbash, 2010). Watts and Zimmerman (1981) defined the auditors' independency as the likelihood the auditor reports honestly if he/she observes a breach, and that the economic theory of auditor independence suggests that auditors trade off the benefits of compromising their independence against the potential loss of reputation and litigation costs that might result from such compromise. DeAngelo (1981) confirmed the above by adding that the future economic interest in a client reduces the auditors' independence vis-à-vis that client.

\subsection{Code of Ethics}

How do people deal with each other? Imagine the world without any ethical framework to deal within, but no matter the religion or the culture and society a person is from they all agree that ethics is the major element for any deal either successful or not.

Othman and Abdul Rahman (2011) defined it as the proper procedure and process of administrative activities and practices in companies, while ethics are built in a person from a young age, which includes honesty, integrity, responsibility and trust. The concept of governing or controlling the humans' ethical aspect is a main assumption in a human civilization. Foucault (1980) argued that ethical changes by an individual can't be achieved by rules, and that individuals are already surrounded by varying discourses and applications that force people and try to discipline their behavior. Ulas and Alakavuklar (2011) said that there are lots of issues that control and make the human personality such as culture, gender and individual orientation. For that this article studied the effect of sex, gender, education, and experience on the credibility gap. They also argued that corporate governance is also a sort of managerial technology/application that tries to control the ethics of the individuals. Kjonstad and Wilmott (1995) said that ethical issues are generally taken as restrictive terms and defined ethics as what one should do and how to control this. While Ibarra-Colado et al. (2006) said "Beware of discourses and create a new ethical managerial subjectivity on the basis of freedom of choice that would interact with ethical environment".

\subsection{Credibility Gap}

Known as a disparity between claims or statements made and the evident fact of the situation or circumstances to which they relate, and for a business to go on such a gap should be narrowed and eliminated if possible. Vogel (2002) said if managers demonstrate prudence and honesty in running their business, they will enjoy positive brand reinforcement that resonates strongly with current interests. Salehi and Rostami (2009) added that a professional management is responsible of lending credible information and as known that auditors are responsible of giving their opinion on the credibility of the information. While Keeffe, (1975) argued that most of the civil or even criminal suits against the auditors are because they failed to see that accounting or financial reporting properly, failed to conduct a proper audit, and thus were guilty and negligent of aiding a fraud, and such an act is called a credibility gap, or responsibility gap.

\section{Literature Review}

Because of the wide definitions of corporate governance lots of literature was presented within the last years, but the more you read in this area the more $u$ feel that it still needs more research, for in Jordan it's true that Amman -Stock exchange made its own corporate governance practices that companies should follow, but still it is only a framework for the companies to work within. O'Sullivan et al. (2008) investigated the role played by a firm's corporate governance framework in the decision to voluntarily disclose forward-looking information in the published financial reports of Australian companies in 2000 and 2002, and results showed a positive relationship between audit quality (presented by independency), board committees, and corporate governance system with the disclosure of forward-looking information for the year 2000. Sappideen (2011) examined the theorized approaches to the corporate governance of listed companies in the US-UK-Australian jurisdictions by highlighting how the hierarchy of corporate governance has been inverted from the board directing the agenda 
and direction of the corporation. The results showed that changes in the jurisdictions were caused by independence of persons determining the compensation process from executive director influence, claw back of compensation awarded on information later found to be based on mis-presentation, and prohibiting the hedging of the "a risk" component of the compensation package.

Siagian (2011) studied corporate governance implementations associated with ownership structure; by using publicly traded firms in Indonesia by using a Corporate Governance Index (CGI) which include family ownership, business group membership, and foreign ownership. The results showed that there was a positive relationship between the CGI score and government ownership, and a negative relationship between the score and family ownership and institutional ownership, which may indicate that majority family and institutional ownership may have objectives that are negatively affected by good corporate governance practices, so they chose not to implement them. The positive relationship between government ownership and corporate governance implementation suggests that the government is consistent with its efforts in promoting corporate governance among public firms in order to protect public interests. But Dube (2011) suggested in his study that corporate governance should be repositioned from the Board of Directors (BOD) to Stakeholders. For it is known that activities of BOD is highly influenced by socio-culture issues within which it operates. More often, their activities are influenced by factors beyond professional training and upbringing. A major of corporate functioning emerges a structural problem (not an agency problem) in a domestic corporate law. While Heng et al. (2012) investigated the relationship between the board of directors and companies capital structure in an emerging market in Malaysia, by covering 75 non-financial leading Malaysian companies, which were employed as a price index; listed on Kuala lumper stock exchange (KLSE) from the year 2005 to 2008 fiscal year, a multiple regression analysis was used. Results revealed that the board size and presence of independent non-executive directors on the board have a significant negative and positive correlation with debt to asset ratio, respectively. But corporate capital structure decisions are not found significantly influenced by $\mathrm{CEO} / \mathrm{chair}$ duality and the presence of non-executive directors on the board. Akindele (2012) examined the relative effect of risk management and corporate governance on bank performance in Nigeria, by utilizing both primary and secondary data. The study revealed that there is a positive relationship between risk management and bank performance, which enhances bank profitability and performance, and results also showed that bank performance depends largely on risk management and corporate governance which lead to better risk management.

Independency of an auditor is a major concept of the audit profession. Ahmed, et al. (2006) studied the importance of the client on an auditor's office, as the importance increases the auditors independence is compromised and the more aggressive it becomes to the clients' accounting. Covering the period from 1999-2011, results showed a significant relation between an office-level measure of client importance and abnormal accruals extenuated for both strong governance and even weak. But Ruiz-Barbadillo et al. (2007) analyzed the independence of audit committees and whether it is affected by the degree of control exerted by managers over the board of directors. The sample included 75 listed Spanish companies whom voluntarily adopted an audit committee between 1998 and 2001. Results showed that the degree of independence is determined by the proportion of inside directors on the board; the same person holding both the CEO and board chairperson positions; and the level of management ownership.

Lots of studies focused on ethics, and how it is important for an auditor to work within a certain code of ethics. Othman and Abdul Rahman (2011) aimed to explore the ethic aspects as a moral substance in relation to corporate governance, by using the qualitative approach. The research chose ethical principles, ethical position and ethical structures as the main elements of ethics that drive the corporations towards inclusive governance practices and several emergent patterns were discovered as variables. Aksoy (2010) analyzed the listed non-financial companies corporate governance and internal auditing performance metrics in Turkey. The findings showed that most companies do not have an internal audit department or even a single internal auditor staff employed. And after considering the recent financial crisis in the world, a number of large corporate failures management called board effectiveness into question. Then the board can therefore be thought of as a team of individuals responsible for developing and selecting creative ideas for the advancement of the company. Kangarluie and Bayazidi (2011) investigated the relationship between corporate governance mechanisms and corporate social responsibility in accepted companies in Tehran Stock exchange by using a questionnaire covering the period 2003-2009. The results showed a relationship between the percentage of institutional ownership and outside directors on the board, and ownership centralization with corporate social responsibility is positive and not significant. However, free float and auditor type had a negative and no significant relation with corporate governance responsibility. Results also showed that bigger companies and companies with higher 
liability ratios have less corporate governance responsibility, and companies that have higher cashflow from operating activities have more corporate governance responsibility.

While Obaidat (2007) studied whether there is an existing gap concerning the importance of accounting information qualitative characteristics from investors and external auditors; as they represent the independent part responsible for the fairness of financial reports; a questionnaire was designed and administered to a sample of 285 investors and 29 auditors. Results showed an existing gap between the external auditors and investors in terms of the qualitative characteristics of the accounting information. Abdullah (2011) suggested a model to measure the impact of auditors' governance on the credibility gap in order to decrease that gap, and auditors in Jordan were taken as the research sample. Results showed a positive relationship between credibility gap and auditors' independency, degree of implementing the auditing standards and quality control standards, and the code of ethics.

\section{Elements of the Problem of the Study}

The study aimed to answer the following questions:

\subsection{First Main Question}

Is there an effect of the auditors' governmental mechanisms on the credibility gap of the accounting information, by studying the following variables: independence of the auditor, and code of ethics of the audit profession?

\subsection{Second Main Question}

Is there a difference between the auditors' governmental mechanisms on the credibility gap of the accounting information while depending on demographic factors?

\section{Hypotheses}

\subsection{First Main Hypothesis}

There is no significant relationship between the auditors' governmental mechanisms and the credibility gap of the accounting information.

And by studying the variables the following sub-hypothesis showed up:

a. First sub-hypothesis:

There is no significant relationship between the independence of the auditor and the credibility gap of the accounting information.

b. Second sub-hypothesis:

There is no significant relationship between the codes of ethics for the audit profession and the credibility gap of the accounting information.

\subsection{Second Main Hypothesis}

There is no significant relationship between the auditors' governmental mechanisms on the credibility gap of the accounting information and the demographic factors (gender, age, education, and experience).

\section{Research Method}

\subsection{Methodology}

The research was carried out by primary data, collected by using a structured questionnaire. In terms of purpose, this study can be useful for an extensive range of users including stockholders, auditors, and other stakeholders. Information was collected through the questionnaire distributed to stockholder representatives in Amman-stock exchange and the data was analyzed by using PASW statistics 18 software.

\subsection{Sample and Statistical Population}

The statistical population in this study included companies' stockholders representatives in Amman-Stock Exchange. The questionnaire was distributed among 120 workers as stockholder representatives, and 102 were recollected.

\section{Measurement}

\subsection{Dependent Variable}

In this research, credibility gap is the dependent variable. For the measurement of this variable, the researcher used Abdullah (2011) questionnaire. 


\subsection{Independent Variables}

\subsubsection{Independency of the Auditor}

Independency refers to the auditor, and the degree of independency auditors' have from parties of financial interest in that business being audited, and the concept requires the auditor to carry out his/her work freely and in an objective manner.

\subsubsection{Degree of Commitment toward the Code of Ethics in the Audit Profession}

Code of ethics principles are adopted by a profession to regulate that profession, and are known as the code of profession responsibility and it includes integrity, objectivity, confidentiality, and competency.

\section{Results and Findings}

The reliability coefficient presented by alpha showed a degree of $95.9 \%$, which is relatively high and accepted for scientific research, and gives a good indication on the formulation of the research tool, accuracy, and consistency of the objectives of the study, which enhances the reliability on the results.

\subsection{Descriptive Statistic Results}

Results showed, as in tables 1 and 2 that almost half of the respondents were males, and that most of the respondents have a bachelor's degree at a rate of $70.6 \%$, and most of them were younger than 35 years, and $88.2 \%$ of them have a 10 year experience or less.

Mean and standard deviation showed that the degree shareholders rely on the independency of auditors and the code of ethics in relation with the credibility gap was relatively high.

Table 1. Descriptive statistics (demographic characteristics)

\begin{tabular}{|c|c|c|c|}
\hline Independent variable & Type of independent variable. & Value & Percentage \\
\hline \multirow[t]{2}{*}{ Gender } & Male & 52 & $51 \%$ \\
\hline & Female & 20 & $49 \%$ \\
\hline \multirow[t]{3}{*}{ Education } & Diploma & 14 & $13.7 \%$ \\
\hline & Bachelors & 72 & $70.6 \%$ \\
\hline & Masters & 16 & $15.7 \%$ \\
\hline \multirow[t]{5}{*}{ Age } & Less than 30 & 36 & $35.3 \%$ \\
\hline & $31-35$ & 42 & $41.2 \%$ \\
\hline & $36-40$ & 20 & $19.6 \%$ \\
\hline & $41-45$ & 2 & $2.0 \%$ \\
\hline & Over 45 & 2 & $2.0 \%$ \\
\hline \multirow[t]{4}{*}{ Experience } & Less than 5 & 40 & $39.2 \%$ \\
\hline & $6-10$ & 50 & $49.0 \%$ \\
\hline & $11-15$ & 8 & $7.8 \%$ \\
\hline & More than 15 & 4 & $3.9 \%$ \\
\hline
\end{tabular}

Table 2. Descriptive statistics (mean and standard deviation)

\begin{tabular}{lllll}
\hline Type of variable & Mean & Standard deviation & Materiality & Degree \\
\hline Independence & 4.16 & 0.69 & 1 & High \\
Code of Ethics & 4.15 & 0.69 & 2 & High \\
Credibility gap & 3.97 & 0.70 & 3 & High \\
\hline
\end{tabular}

7.2 What Is the Correlation between Auditors' Independency, and Code of Ethics as Factors of Corporate Governance on the Credibility Gap?

Pearson correlation is used to answer such a question as in table 3, and for scientific research a correlation of 0.01 is significant and means that there is a strong relationship between the dependent and independent variables, but results were even better and the correlation appeared at a level of 0.000 significance for both independency and code of ethics. 
Table 3. Pearson Correlation

\begin{tabular}{lll}
\hline & Independency & Code of ethics \\
\hline Credibility Gap(Pearson) & 0.623 & 0.645 \\
Credibility Gap(correlation) & $0.000^{*}$ & $0.000^{*}$ \\
\hline
\end{tabular}

Note: * Significant at a level of 0.01 .

\subsection{Hypotheses Testing Results}

To test the first main hypothesis Adjusted R Square was used to see the models predictive ability, and simple regression was also used to test the effectiveness of the auditors' independency, code of ethics and the demographic factors on the credibility gap as in tables 4, 5,6 and 7 .

Results showed a positive significant relationship between the auditors' independency and the credibility gap, for $\mathrm{t}$ was 7.970 for the auditors' independency variable at a level of 0.000 significance, so the first-sub null hypothesis was rejected.

And the results also showed a positive significant relationship between the code of ethics and the credibility gap, and $\mathrm{t}$ was 8.436 for the code of ethics variable at a level of 0.000 significance, so also the second-sub null hypothesis was rejected.

Table 4. Analyze of variance (First sub-hypothesis)

\begin{tabular}{lllllll}
\hline & df & Sum of squares & Mean squares & F & Sig. & Adjusted R Square \\
\hline Regression & 1 & 19.261 & 19.261 & 63.527 & $0.000^{*}$ & 0.382 \\
Residual & 100 & 30.319 & 0.303 & & & \\
\hline
\end{tabular}

Note: * Significant at a level of 0.01 .

Table 5. Analyze of variance (Second sub-hypothesis)

\begin{tabular}{lllllll}
\hline & df & Sum of squares & Mean squares & F & Sig. & Adjusted R Square \\
\hline Regression & 1 & 20.615 & 20.615 & 71.173 & $0.000^{*}$ & 0.410 \\
Residual & 100 & 28.965 & 0.290 & & & \\
\hline
\end{tabular}

Note: * Significant at a level of 0.01 .

Table 6. Simple Regression (First sub-hypothesis)

\begin{tabular}{llllll}
\hline Variable & B & Std. Error & Beta & t & Sig. \\
\hline Auditors independency & 0.636 & 0.080 & 0.623 & 7.970 & $0.000^{*}$ \\
\hline
\end{tabular}

Note: * Significant at a level of 0.01 .

Table 7. Simple Regression (Second sub-hypothesis)

\begin{tabular}{llllll}
\hline Variable & B & Std. Error & Beta & t & Sig. \\
\hline Code of ethics & 0.654 & 0.078 & 0.645 & 8.436 & $0.000^{*}$ \\
\hline
\end{tabular}

Note: * Significant at a level of 0.01 .

In order to test the second main hypothesis One Way Anova was used including Post Hoc tests (Sheffe, and Dunett's C) to test the degree of homogeneity presented in table 8. Results showed a positive significant relationship for the gender variable for $\mathrm{F}$ was (5.29) at a significant level of (0.024), and results showed that the females were more realizable of the effect of the credibility gap than the males; for the mean was (4.128) for the females, and (3.8154) for the males. But for age, education and experience years results showed that there is no significant relationship between those remaining variables and the credibility gap, so the second main hypothesis was accepted except for the gender variable. 
Table 8. One Way Anova (second main hypothesis)

\begin{tabular}{|c|c|c|c|c|c|}
\hline Demographic variables & Type of variable & Mean & df & $\mathrm{F}$ & Sig. \\
\hline \multirow[t]{2}{*}{ Gender } & Male & 3.8154 & \multirow{2}{*}{1} & \multirow{2}{*}{5.290} & \multirow{2}{*}{$0.024^{*}$} \\
\hline & Female & 4.1280 & & & \\
\hline \multirow[t]{3}{*}{ Education } & Diploma & 4.0857 & \multirow{3}{*}{2} & \multirow{3}{*}{0.749} & \multirow{3}{*}{0.476} \\
\hline & Bachelors & 3.9139 & & & \\
\hline & Masters & 4.1125 & & & \\
\hline \multirow[t]{5}{*}{ Age } & Less than 30 years & 4.0833 & \multirow{5}{*}{4} & \multirow{5}{*}{1.181} & \multirow{5}{*}{0.324} \\
\hline & $31-35$ & 3.9190 & & & \\
\hline & $36-40$ & 3.7700 & & & \\
\hline & $41-45$ & 4.5000 & & & \\
\hline & Over 45 years & 4.4000 & & & \\
\hline \multirow[t]{4}{*}{ Experience } & Less than 5 years & 4.0650 & \multirow{4}{*}{3} & \multirow{4}{*}{1.532} & \multirow{4}{*}{0.211} \\
\hline & $6-10$ & 3.9120 & & & \\
\hline & $11-15$ & 3.6250 & & & \\
\hline & More than 15 years & 4.4000 & & & \\
\hline
\end{tabular}

Note: * Significant at a level of 0.05 .

\section{Summary and Conclusion}

While the purpose of the study is to explore the relationship between auditors' independency and code of ethics on the credibility gap in terms of shareholders, results showed a positive effect of audit independency and code of ethics on the credibility gap. For the more independent the auditor is, the more faithful the information presented by him/her will be. And the higher the auditor implements the code of ethics; the presentation of faithful information is expected to be higher. While results showed that the only demographic factor that had a relationship with the credibility gap was gender, where females were more understanding of the importance of the credibility gap.

\section{Limitations and Recommendations for Future Research}

The target of this paper was to explore the relationship between corporate governance represented by the auditors' independency and the code of ethics with the credibility gap. Hence, the results may not represent the whole population of shareholders, because, in Jordan it is very hard to directly contact with them, so their substitutes were their representatives.

Moreover in this study only independency and code of ethics and demographic factors were the variables used to examine credibility gap. The main reason for that is that the researcher didn't want to increase the length of the questionnaire, for it is known that the representatives are almost busy the whole day with daily deals, and their time is limited. For that it is recommended to study other corporate governance factors that could affect the credibility gap, such as the degree of implementing International Standards of Accounting, and the International Standards of Quality Control. And it is also recommended to study the relationship between corporate governance and risk management by taking into account shareholders view.

\section{References}

Abdullah, A. A. (2011). A suggested model for measuring the role of auditor governance and its impact on the credibility gap of accounting information. (Unpublished doctoral dissertation). Amman-Arab University, Jordan.

Aguilera, R. V., \& Jackson, G. (2003). The cross-national diversity of corporate governance: Dimensions and determinants. Academy of Management Review, 28(3), 447-465. http://dx.doi.org/10.2307/30040732

Akindele, R. I. (2012). Risk Management and corporate Governance Performance - Empirical Evidence from the Nigerian Banking Sector. Ife PsychologIA, 20(1), 103-120.

Aksoy, T. (2010). The Role of Modern Internal Auditing and Corporate Governance in Turkey. MÖDAV, 4, $15-45$.

Answer, A., Duellman, S., \& Abdel Meguid, A. (2006). Auditor Independence, Corporate Governance and Abnormal Accruals. Workshop, Syracuse, US.

Bandyopandhyay, R. (2011). Going Beyond Corporate Governance. Retrieved from http://www.iodonline.com/articles. 
Berenbeim, R. (2012). Corporate Governance in Emerging Markets ... and Everywhere Else. Vital Speeches International, 4(2), 43-47.

Cadbury, A. (2000). The Corporate Governance Agenda. Corporate Governance, 8(1), 7-15. http://dx.doi.org/10.1111/1467-8683.00175

Cakar, U., \& Alakavuklar, O. (2011). Ethics by decree facing the freedom of choice: examining the treatise of corporate governance of control. MÖDAV, 4, 241-257.

DeAngelo, L. (1981). Auditor independence, 'low balling', and disclosure regulation. Journal of Accounting and Economics, 3, 113-127. http://dx.doi.org/10.1016/0165-4101(81)90009-4

Dube, I. (2011). Is Corporate Governance the Answer to Corporate Structural Failure? US-CHINA Law Review, 8(5), 413- 430.

Foucault, M. (1980). Power/Knowledge: Selected Interviews and Other Writings 1972-1977. C. Gordon (Ed.) (C. Gordon, L. Marshall, J. Mepham and K. Soper, Trans.). New York: Pantheon.

Gopinath, V. (2010). Ethical corporate governance. Retrieved from http://www.lawyersclubindia.com/article.

Habbash, M. (2010). The effectiveness of corporate governance and external audit on constraining earnings management practices in the UK. (Doctoral Dissertation). Retrieved from http://www.ebscohost.net.

Heng, T. B., Azrbaijani, S., \& San, O. T. (2012). Board of Directors and Capital Structure: Evidence from Leading Malaysian Companies. Asian Social Science, 8(3), 123-136. http://dx.doi.org/10.5539/ass.v8n3p123

Ibarra-Colado, E., Clegg, S., Rhodes, C., \& Kornberger, M. (2006). The ethics of managerial subjectivity. Journal of Business Ethics, 64, 45-55. http://dx.doi.org/10.1007/s10551-005-3325-z

John, K., \& Senbet, L. (1998). Corporate Governance and Board Effectiveness. Journal of Banking and Finance, 22(4), 371-403. http://dx.doi.org/10.1016/S0378-4266(98)00005-3

Kangarluie, S. J., \& Bayazidi, A. (2011). Corporate Governance Mechanisms and Corporate Social Responsibility (CSR): Evidence from Iran. Australian Journal of Basic and Applied Sciences, 5(9), 1591-1598.

Keeffe, A. J. (1975). When Accountants Fall into the Credibility Gap. American Bar Association Journal, 61(8), 993-994.

Kjonstand, B., \& Willmott, H. (1995). Business ethics: Restrictive or empowering. Journal of Business Ethics, 14, 445-464. http://dx.doi.org/10.1007/BF00872086

Ma'atoofi, A. R., \& Ahmadian, A. A. (2011). Corporate Governance, the Adoption of a Balanced Strategic Approach in Iran's Capital Market. European Journal of Social Sciences, 22(2), 237- 248.

O'Sullivan, M., Percy, M., \& Stewart, J. (2008). Australian evidence on corporate governance attributes and their association with forward-looking information in the annual report. Journal of Manage Governance, 12, 5-35. http://dx.doi.org/10.1007/s10997-007-9039-0

Obaidat, A. N. (2007). Accounting Information Qualitative Characteristics Gap: Evidence from Jordan. International Management Review, 3(2), 25-32.

Othman, Z., \& Abdul Rahman, R. (2011). Exploration of ethics as Moral Substance in the Context of Corporate Governance. Asian Social Sciences, 7(8), 173-182.

Picou, A., \& Rubach, M. J. (2006). Does good Governance Matter to Institutional Investors? Evidence from the Enactment of Corporate Governance Guidelines. Journal of Business Ethics, 65(1), 55-67. http://dx.doi.org/10.1007/s10551-006-0016-3

Rodrigues, U. (2011). Corporate Governance in an Age of Separation of Ownership from Ownership. Minnesota Law Review, 95, 1822-1866.

Ruiz-Barbadillo, E., López, E. B., \& Gómez-Aguilar, N. (2007). Managerial dominance and audit committee independence in Spanish corporate governance. $J$ Manage Governance, 11, 311-352. http://dx.doi.org/10.1007/s10997-007-9035-4

Salehi, M., \& Rostami, V. (2009). Audit expectation Gap: International Evidences. International Journal of Academic Research, 1(1), 140-146.

Sappideen, R. (2011). Corporate governance and the Surrogates of Managerial Performance. UNSW Law 
Journal, 34(1) 136-158.

Scheifer, A., \& Vishny, R. (1997). A Survey of Corporate Governance. Journal of Finance, 52(2), 737-783. http://dx.doi.org/10.1111/j.1540-6261.1997.tb04820.x

Siagian, F. T. (2011). Ownership Structure and Governance Implementation: Evidence from Indonesia. International journal of Business, Humanities and Technology, 1(3), 187-202.

Vogel, B. (2002). The CEO Credibility Gap. Adweek Magazines’ Technology Marketing, 22, 22-26.

Waats, R., \& Zimmerman, J. (1981). The Markets for independence and independent auditors. Working paper, University of Rochester. 